\title{
HORYZONT INTERPRETACYJNY \\ TZW. „SYTUACJI NIEREGULARNYCH” (AMORIS LAETITIA) W ŚWIETLE NAUCZANIA JANA PAWŁA II ORAZ DOKUMENTU MIĘDZYNARODOWEJ KOMISJI TEOLOGICZNEJ PT. INTERPRETACJA DOGMATÓW*
}

\author{
INTERPRETATIVE HORIZON OF SO-CALLED „IRREGULAR SITUATIONS” \\ (AMORIS LAETITIA) IN THE LIGHT OF THE TEACHING OF JOHN PAUL II \\ AND THE DOCUMENT OF THE INTERNATIONAL THEOLOGICAL COMMISSION \\ THE INTERPRETATION OF DOGMA
}

\begin{abstract}
A b s t r a c t. This article is devoted to the issue of interpreting the teaching of Pope Francis on the so-called "Irregular situations" presented in the exhortation Amoris laetitia. This is an important problem because this part of papal theology raises the most controversy. Looking at the dynamics of the development of the Church's doctrine, one can easily see its constant development towards the better clarification of the truths of faith as well as the constant updating of teaching. However, every updating must be immersed in Tradition because the truth remains unchanged in its essence, and only a certain language form of its message can change. Adopting the hermeneutics of continuity that characterizes the development of the Church's doctrine, it is entitled to search for the right hermeneutic context for "irregular situations" in the light of the theology and anthropology of John Paul II and against the background of the International Theological Commission document dedicated to the interpretation of dogmas.
\end{abstract}

Key words: John Paul II; Francis; ,irregular situations”; Amoris laetitia, the interpretation of dogma; hermeneutics.

Dr Michą Kosche - teolog, personalista, asystent naukowy w Katedrze Chrystologii i Personalizmu Chrześcijańskiego KUL; adres do korespondencji: e-mail: michal.kosche@ gmail.com; ORCID: 0000-0002-1715-1510.

* „Projekt finansowany w ramach programu Ministra Nauki i Szkolnictwa Wyższego pod nazwa „Regionalna Inicjatywa Doskonałości” w latach 2019-2022, nr projektu 028/RID/2018/19, kwota finansowania $11742500 \mathrm{zl}$ ”. 


\section{WSTĘP}

Problematyka związana z życiem małżeńskim stanowi od wieków jedną z najważniejszych przestrzeni nauczania Kościoła. Dlatego też nie może dziwić, że wzbudza ona niesłabnące zainteresowanie ze strony wiernych świeckich. Jako pełnoprawna doktryna Kościoła nauka o małżeństwie, będącym rzeczywistością sakramentalną i wyjątkową relacją międzyludzką, zakorzeniona jest w Ewangelii i posiada swoje ugruntowanie w Tradycji. Prawdą jest i to, że podlega ona także pewnemu rozwojowi i konieczności szukania wciąż nowych dróg interpretacji, pomagających w lepszym zrozumieniu i przyswojeniu tego nauczania przez wiernych. Prawda dogmatyczna o małżeństwie, jak i każda inna, musi przynosić owoce w teraźniejszym życiu Kościoła. Dlatego też przed każdym pokoleniem teologów powstaje, wciąż na nawo, ogromne zadanie polegające na konieczności zaprezentowania wierzącym ,interpretacji aktualizującej” dobrej nowiny o małżeństwie w świetle Biblii i Tradycji. Owa interpretacja powinna być osadzona na dwóch fundamentalnych zasadach: trwałej wartości prawdy oraz nieustannej aktualności prawdy. „Oznacza to, że nie można ani zrezygnować z Tradycji lub złamać jej, ani - pod pretekstem wierności - przekazywać skostniałego zwyczaju. Chodzi o to, by z pamięci Tradycji rodziła się nadzieja dla teraźniejszości i dla przyszłości. Definicja może być w końcu znacząca dla teraźniejszości tylko dlatego, że jest prawdziwa i w jakiej mierze jest prawdziwa. Trwała ważność prawdy i jej aktualność warunkują się więc wzajemnie. Tylko prawda wyzwala (por. J 8,32)"'

W związku z powyższym, szczególnie wymagającym zadaniem dla teologii na dziś staje się właściwe zinterpretowanie nauczania zawartego przez papieża Franciszka w adhortacji Amoris laetitia na temat tzw. „sytuacji nieregularnych”. Ta część wykładu papieskiego budzi bowiem największe kontrowersje. Poszukiwanie właściwego horyzontu interpretacyjnego dla zrozumienia skomplikowanej sytuacji małżonków znajdujących się w ,sytuacji nieregularnej” rodzi, implicite w punkcie wyjścia, potrzebę właściwego zrozumienia zasad rozwoju nauczania Kościoła w organicznej łączności wymiaru doktrynalnego i pastoralnego. Jak już wcześniej zaznaczyliśmy interpretacja aktualizująca musi być zanurzona w Tradycji, ponieważ prawda pozostaje w swojej istocie niezmienna, a jedynie zmieniać się może pewna forma językowa jej przekazu. Dlatego też w punkcie wyjścia procesu poszukiwania właściwego horyzontu hermeneutycznego nauczania

1 Międzynarodowa Komisja TeOlogiczna, Interpretacja dogmatów, Rzym 1988, nr C.III.1. 
zawartego w Amoris laetitia, chcielibyśmy postawić tezę o organicznej łączności nauczania papieża Franciszka oraz papieża Jana Pawła II w kluczu doktrynalnej hermeneutyki ciągłości. Ta zaś teza uzasadnia próbę naszkicowania horyzontu interpretacyjnego tzw. ,sytuacji nieregularnych” właśnie w świetle nauczania Jana Pawła II.

Aby jak najlepiej nakreślić sytuację osób żyjących w tzw. „sytuacjach nieregularnych" szczegółowe analizy zaprezentowane w niniejszym artykule zostaną uporządkowane w pewnym kluczu. Po pierwsze zostanie przedstawiona wizja teologii komunijnej uwzględniającej szczególną więź sakramentalności małżeństwa z sakramentalnością Kościoła i Eucharystią. Następnie uwaga poznawcza zostanie skierowana $\mathrm{w}$ stronę filozoficznej analizy normy personalistycznej jako fundamentu relacji małżeńskiej o profilu oblubieńczym. Kolejny punkt będzie zawierał argumentację płynącą z rozpoznania stosunku osądu sumienia do obiektywnej wartości moralnej czynu. Całość zwieńczy analiza zasad rozwoju doktryny na tle dokumentu Międzynarodowej Komisji Teologicznej poświęconemu interpretacji dogmatów.

\section{ARGUMENTACJA TEOLOGICZNA}

Papież Franciszek, podejmując analizę tzw. „sytuacji nieregularnych”, opiera się na dwóch fundamentalnych zasadach. Po pierwsze, osoby rozwiedzione a żyjące $\mathrm{w}$ nowych związkach partnerskich powinny być traktowane w perspektywie wielkiego miłosierdzia. Po drugie, nie może być mowy o jakimkolwiek minimalizowaniu wymagań Ewangelii ${ }^{2}$ czy wyrzeczeniu się przez Kościół promowania pełnego ideału małżeństwa ${ }^{3}$. W związku z powyższym zasadne jest przybliżenie ideału małżeństwa w jego perspektywie teologicznej oraz personalistyczno-moralnej, aby zrozumieć o jaki ideał chodzi Kościołowi. Na tym tle możliwe będzie właściwe rozpoznanie postulatu Papieża o przyjęciu logiki miłosierdzia jako właściwego sposobu podejścia do osób żyjących stale na sposób małżeński (more uxorio) z osobą, która nie jest prawowitą małżonką albo prawowitym mężem.

Właściwą perspektywą teologiczną do rozważań na temat małżeństwa jest kategoria communio personarum. Choć filozoficzno-antropologiczne zaplecze dla tego ujęcia można odnaleźć w kategorii uczestnictwa, bezinteresownego daru z siebie czy miłości oblubieńczej, to najwłaściwszy horyzont rozumienia tego,

\footnotetext{
2 Por. FrancisZeK, Adhortacja Amoris laetitia, Rzym 2016, nr 301.

${ }^{3}$ Por. tamże, nr 307.
} 
czym jest w swej najgłębszej istocie communio personarum, znajduje się w samym sercu teologii - w trynitologii, jako nauce o Osobach Boskich połączonych ze sobą relacjami tak ścisłymi, że stanowiącymi jedną Istotę, doskonałą Wspólnotę miłości, do której w Chrystusie przez Ducha Świętego z woli Ojca zaproszone są wszystkie istoty osobowe. Wynika stąd jasno, że bezpośrednim pierwowzorem komunii pomiędzy mężczyzną a kobietą jest sama Komunia Trójcy Świętej". Owa komunia jest zatem przestrzenią szczególnego rodzaju podobieństwa człowieka w jego wymiarze międzyosobowym do Boga bytującego na sposób interpersonalny ${ }^{5}$.

Optyka trynitologiczna w nauczaniu Jana Pawła II jest ściśle zjednoczona z chrystologią i perspektywą przebóstwienia. Przebóstwienie w swojej istocie polega na udziale w wewnętrznym życiu samego Boga. Jest nasyceniem i przeniknięciem człowieka tym, co istotowo Boskie. Jest ukształtowaniem ludzkiej podmiotowości we wspólnocie ludzkiej na wzór zjednoczenia z Bogiem w Jego trynitarnej tajemnicy i obcowania $\mathrm{z}$ Nim $\mathrm{w}$ doskonałej komunii osób ${ }^{6}$. Jest to możliwe nawet po ludzkim upadku moralnym, ponieważ Chrystus jest tym, który pozwala człowiekowi przygniecionemu grzechem na nowo wejść w relację o profilu komunijnym, zamierzoną przez Boga $\mathrm{w}$ akcie stworzenia ${ }^{7}$. Człowiek może zatem urzeczywistnić communio personarum jedynie dzięki przyjęciu i współpracy z Chrystusową łaską odkupienia. Dawcą łaski sic et nunc jest Duch Chrystusa, który uświęca każdego. Obdarowuje on wspólnotę międzyludzką nade wszystko miłością, sam bowiem jest Miłością-Osobą ${ }^{8}$.

Hermeneutyka chrystologiczna jest ściśle związana z sakramentalnością małżeństwa. Poprzez ten „znak” i w tym „znaku” Bóg udziela się człowiekowi i urzeczywistnia się w nim (w nich) dzieło zbawienia zamierzone przez Ojca i dokonane w Duchu „do końca” w Chrystusie ${ }^{9}$. Dlatego też można za Papieżem powiedzieć, że w perspektywie ekonomii sakramentalnej, wychodząc od chrztu, małżonkowie jednoczą się z Chrystusem i z sobą wzajemnie przez wszystkie

\footnotetext{
${ }^{4}$ W.E. MAY, La 'communio personarum' e l'atto coniugale, w: Morale Coniugale e Sacramento della Penitenza: Riflessioni sul 'Vademecum per i Confessori', red. A. Card, L. Trujillo, F.G. Hellin, Roma 1998, s. 135-150.

${ }^{5}$ Por. JAN PAWEe II, Mężczyzna i niewiasta stworzyt ich. Odkupienie ciała a sakramentalność matżeństwa, Lublin 2011, s. 33.

${ }^{6}$ Por. tamże, s. 226.

${ }^{7}$ Por. JAN PAWEe II, Adhortacja „Familiaris consortio”, Rzym 1981, nr 3.

${ }^{8}$ Por. JAN PAWEŁ II, List do rodzin „Gratissimam sane”, Rzym 1994, nr 7; JAN PAWEŁ II, Encyklika „Dominum et Vivificantem”, Rzym 1986, nr 10.

${ }^{9}$ Por. JAN PAWEŁ II, Mężczyzna i niewiasta stworzyt ich. Odkupienie ciała a sakramentalność matżeństwa, s. 267.
} 
sakramenty, jednakże najściślej dokonuje się to przez Eucharystię. Jest ona „Zwieńczeniem” wszystkich sakramentów, dzięki którym człowiek może osiągnąć komunię z Bogiem ${ }^{10}$. Istnieje pewna analogia pomiędzy darem ,ciała” Chrystusa, który udziela się w Eucharystii, a darem „ciała”, w którym małżonkowie starają się urzeczywistnić komunię między sobą. Droga małżeńska jest swego rodzaju droga „odkupienia ciała” analogiczną do drogi odkupienia Kościoła jako Oblubienicy Chrystusa ${ }^{11}$.

Na przedłużeniu małżeńskiego communio personarum Ojciec Święty rozwija komunijny charakter całej rodziny chrześcijańskiej. Jest to niezwykle ważne w kontekście naszych analiz, ponieważ stosunek do dzieci ujawnia się jako rzeczywistość niezwykłej wagi na drodze właściwego rozeznawania tzw. „sytuacji nieregularnych". Papież rodzicielstwo postrzega jako naturalną konsekwencję obdarowywania się wzajemnie sobą przez dwoje ludzi. Jest to niejako inny sposób urzeczywistniania się miłości oblubieńczej: „tak jak dobro wspólne małżeństwa urzeczywistnia się poprzez miłość oblubieńczą, która gotowa jest dawać i przyjmować nowe życie - tak dobro wspólne rodziny urzeczywistnia się przez tę samą oblubieńczą miłość spełnioną w nowo narodzonym"12. Rodzina ma swój fundament w trwałej wspólnocie małżeńskiej, która do prawidłowego rozwoju wymaga umacniania zarówno na drodze naturalnej - poprzez osobiste zaangażowanie małżonków w obdarowywaniu się miłością - jak i nadprzyrodzonej - poprzez dar komunii, który małżonkowie otrzymali od Ducha Świętego w sakramencie ich jedności. Oba te wymiary są ożywiane w sposób najwyższy jedynie poprzez autentyczne i pełne zaangażowania uczestnictwo w Eucharystii. Ostatecznie tylko „,w darze eucharystycznym miłości rodzina chrześcijańska znajduje podstawę i ducha ożywiającego jej „komunię” i jej „posłannictwo”: Chleb eucharystyczny czyni z różnych członków wspólnoty rodzinnej jedno ciało, objawienie szerszej jedności Kościoła i uczestnictwo w niej; uczestnictwo w Ciele „wydanym” i Krwi „przelanej” Chrystusa staje się niewyczerpanym źródłem misyjnego i apostolskiego dynamizmu rodziny chrześcijańskiej"13.

Podążając dalej tropem analogii pomiędzy sakramentalnym małżeństwem a Eucharystią, należy także zwrócić uwagę na rozumienie samego Kościoła jako wspólnoty communio. Kościół to nade wszystko przestrzeń szczególnego do-

\footnotetext{
${ }^{10}$ Por. Jan PaweŁ II, Encyklika „Ecclesia de Eucharistia”, Rzym 2003, nr 34.

${ }^{11}$ Por. M. POKRYwKA, Rola Eucharystii w budowaniu matzeńskiej „communio personarum”, RT 52(2005), z. 3, s. 57-60; JAN PAWEE II, Mężczyzna i niewiasta stworzyt ich. Odkupienie ciała a sakramentalność matżeństwa, s. 297-311.

12 JAN PAWEE II, List do rodzin „Gratissimam sane”, nr 11.

13 JAN PAWEe II, Adhortacja „Familiaris consortio”, nr 57.
} 
świadczenia komunijnej i zbawczej obecności Trójjedynego Boga. W adhortacji Ecclesia In Oceania Jan Paweł II napisał: „Kościelne communio jest darem Trójcy Świętej, której głębokie życie wewnętrzne jest w sposób cudowny dzielone z ludzkością. Communio jest owocem Bożej inicjatywy miłości, wypełnionej w paschalnym misterium Chrystusa, przez które Kościół uczestniczy w boskim communio miłości pomiędzy Ojcem i Synem w Duchu Świętym. „Boża miłość została rozlana w sercach naszych przez Ducha Świętego, który został nam dany” (Rz 5,5). W dniu Zielonych Świąt, Pascha Chrystusa została doprowadzona do końca przez wylanie Ducha, który dał nam pierwsze owoce naszego dziedzictwa, udział w życiu Trójjedynego Boga, który uzdalnia nas do miłowania tak, ,jak Bóg nas umiłował" (1 J 4,11)"14.

Na przedłużeniu tej komunijnej wspólnoty wertykalnej wyrasta horyzontalne communio sanctorum. Zgodnie $\mathrm{z}$ wykładnią Communionis notio istnieje dwojaki sens określenia communio sanctorum: pierwszy to komunia w „rzeczach świętych" (sancta), drugi to komunia pomiędzy osobami świętymi (sancti) $)^{15}$. Oba wymiary spaja właśnie communio eucharistica. Przy czym zgodnie z genialną metodą personalistyczną Papieża Eucharystia nie tylko tworzy komunię w sensie obiektywnym, lecz także wychowuje do komunii, czyli pozwala na podmiotowe przyjęcie tego wielkiego daru, jakim jest jedność z Bogiem i innymi ludźmi ${ }^{16}$. Ojciec Święty, powtarzając za św. Cyprianem, że Kościół to „lud zjednoczony jednością Ojca i Syna, i Ducha Świętego"17, podkreśla na pierwszym miejscu obiektywną - bo płynącą z mocy Bożej - moc komuniotwórczą tego sakramentu. Jednakże zaraz potem zwraca uwagę na potrzebę kształtowania świadomości owej komunii, na czynne w niej uczestnictwo, na zaangażowanie w jej urzeczywistnianie, które jest także niezbędne do stworzenia realnej i pełnej komunii (communio perfecta).

Tylko w Chrystusie, za pośrednictwem Ducha Świętego i z woli Ojca, wertykalny wymiar Eklezji stale rozprzestrzenia się na jej horyzontalną płaszczyznę. Dlatego też kiedy na wspólnotę wiary popatrzy się przez pryzmat Chrystusowego odkupienia, ujawnia się właściwa teologiczna perspektywa rozumienia Kościoła jako Ciała Mistycznego Chrystusa. W tej optyce zostaje ujawniony fakt, że świadomość obdarowania przez Trójcę darami zbawczymi jest uprzednia względem świadomości bycia Ludem Bożym. Kościół jako Oblubienica, podobnie jak sakra-

14 JAN PAWEŁ II, Adhortacja „Ecclesia In Oceania”, Rzym 2001, nr 10.

${ }^{15}$ Zob. J. RATZINGER, List do biskupów Kościoła katolickiego o niektórych aspektach Kościoła pojętego jako komunia „Communionis notio”, Rzym 1992.

16 Por. JAN PAWEŁ II, Encyklika „Ecclesia de Eucharistia”, nr 40.

${ }^{17}$ Por. Jan PAweE II, Adhortacja „Christifideles laici”, nr 18. 
mentalne małżeństwo, posiada teologiczny sens jedynie w przypadku rzeczywistej wspólnoty z Trójcą o charakterze komunijnym. Kiedy brakuje realnej osobowej komunii pomiędzy Bogiem a człowiekiem, np. ze względu na niewłaściwą dyspozycję człowieka, nie ma mowy o osobowej i komunijnej relacji człowieka z Bogiem, a nawet o wewnętrznej komunijnej relacji członków Kościoła między sobą. Wymiar wspólnotowy Kościoła musi być postrzegany zawsze w perspektywie wertykalnej, w optyce jedności, która płynie od samego Boga, a która dzięki Jego łasce urzeczywistnia się także pośród wierzących. Dzieje się tak za sprawą aktywnego działania Ducha Świętego. Jan Paweł II klaruje, że „o jedności pomiędzy członkami nowego Ludu - a jeszcze wcześniej, o ich jedności z Chrystusem - stanowią więzy nie „ciała” i „krwi”, lecz „ducha”, a ściślej więzy Ducha Świętego, którego wszyscy ochrzczeni otrzymują w darze"18. Dochodzi tu do głosu działanie Parakleta, który stanowi zawsze dynamiczną zasadę jedności i różnorodności Kościoła ${ }^{19}$. Jedność Kościoła jest zatem wyraźnie oparta na działaniu Ducha Świętego łączącego wierzących z Ciałem Chrystusa. Eucharystia jest ukonkretnieniem tego działania Boskiego Parakleta. W związku z tym kiedy brak jedności z Duchem Świętym, wyrażającej się choćby w życiu zgodnym z Jego natchnieniami, prawami, które objawił człowiekowi na kartach Ewangelii czy w Tradycji Kościoła, nie ma mowy o pełnej komunii człowieka z Bogiem, choćby nawet człowiek przyjmował fizycznie Najświętsze Ciało i Krew.

Powyższy zarys teologii sakramentalnego małżeństwa stawia dość jasne granice hermeneutyczne interpretacji tzw. „sytuacji nieregularnych”, o których pisze Franciszek. Sam Jan Paweł II wyraził je zresztą klarownie w swojej adhortacji Familiaris consortio w numerze 84: „Kościół jednak na nowo potwierdza swoją praktykę, opartą na Piśmie Świętym, niedopuszczania do komunii eucharystycznej rozwiedzionych, którzy zawarli ponowny związek małżeński. Nie mogą być dopuszczeni do komunii świętej od chwili, gdy ich stan i sposób życia obiektywnie zaprzeczają tej więzi miłości między Chrystusem i Kościołem, którą wyraża i urzeczywistnia Eucharystia. Jest poza tym inny szczególny motyw duszpasterski: dopuszczenie ich do Eucharystii wprowadzałoby wiernych w błąd lub powodowałoby zamęt co do nauki Kościoła o nierozerwalności małżeństwa". Papież, zgodnie z hermeneutyką miłosierdzia Bożego, wprowadza możliwość dopuszczenia do sakramentu pokuty i pojednania, a przez to do stołu Eucharystycznego osób, które dla ważnych powodów (jak na przykład wychowanie dzieci) nie mogą zakończyć niesakramentalnych związków. Ojciec Święty stawia jednak

\footnotetext{
18 Tamże, nr 19.

19 Por. tamże, nr 20.
} 
w takich przypadkach warunek konieczny - czyli wstrzemięźliwość seksualną. Nie jest to wymóg natury jedynie dyscyplinarnej czy też kara za nieudany związek sakramentalny, ale wymóg wypływający wprost z sakramentalnego i personalistycznego rozumienia małżeństwa jako przymierza osób na wzór zjednoczenia Chrystusa z Kościołem oraz wewnętrznej miłości samych Osób Bożych.

Kościół zatem nie może uznać ważności nowego związku, jeśli poprzednie małżeństwo jest ważne. Nie jest to jedynie teoria, lecz praktyka potwierdzana wielokrotnie w historii Kościoła, o czym przekonuje choćby prefekt Kongregacji Nauki Wiary kardynał Joseph Ratzinger w dokumencie wydanym w 1994 r. zatytułowanym List do biskupów Kościoła katolickiego na temat przyjmowania Komunii świętej przez wiernych rozwiedzionych żyjacych w nowych zwiazkach. Kardynał w odniesieniu do praktyk dopuszczania do Eucharystii osób rozwiedzionych, będących w nowych związkach partnerskich, stwierdza w numerze 4 tegoż dokumentu, że choć ,analogiczne rozwiązania duszpasterskie były proponowane przez niektórych Ojców Kościoła i w pewnej mierze były stosowane w praktyce, to nie zostały one nigdy zaaprobowane przez Ojców i w żaden sposób nie stanowiły powszechnej nauki Kościoła, ani nie znalazły się w jego dyscyplinie. Obowiązkiem powszechnego Magisterium Kościoła, w imię wierności Pismu Świętemu i Tradycji, jest nauczanie oraz autentyczne interpretowanie depozytu wiary".

Kardynał Gerhard Ludwig Müller, powołując się na autentyczny i uprawniony rozwój nauczania Kościoła, opowiada się za możliwością pokuty i pojednania sakramentalnego prowadzącego do możliwości przyjmowania Eucharystii dla tych osób, które są w sumieniu przekonane o nieważności pierwszego związku małżeńskiego. Oczywiście, kiedy nieważność zostaje stwierdzona przez sąd biskupi, sprawa jest jasna i klarowna. Kardynał postuluje jednak, aby w sytuacjach trudnych, w których nie można uzyskać takiego wyroku z uwagi na różne okoliczności życiowe (np. złą wolę współmałżonka, brak dowodów, które można przedstawić w sądzie), spowiednik rozeznający sytuację takiej osoby, jeśli są ku temu podstawy, mógł warunkowo dopuścić ją do sakramentów. Wieloletni prefekt Kongregacji Nauki Wiary zauważa, że czasem kiedy człowiek nawraca się w wieku dojrzałym, towarzyszy mu świadomość tego, że jego poprzednie małżeństwo nie było sakramentem. „W takiej sytuacji - stwierdza Kardynał - napięcie, jakie pojawia się tu pomiędzy publicznym, obiektywnym statusem „drugiego" małżeństwa a subiektywną winą może, w pewnych opisanych wyżej okolicznościach, otworzyć drogę do sakramentu pokuty i do przyjęcia komunii świętej, dzięki rozeznaniu duszpasterskiemu i towarzyszeniu" 20 .

\footnotetext{
${ }^{20}$ G.L. MÜLLER, Przedmowa. Dlaczego adhortacja „Amoris Laetitia” może i powinna być
} 
Oczywiście w takim przypadku należy zastanowić się nad przytoczonym wcześniej stanowiskiem J. Ratzingera. Powstaje pytanie o relację osobistego przeświadczenia o nieważności sakramentu do jego ważności obiektywnej stwierdzonej przez Kościół. Kwestia ta zostanie podjęta w dalszej części artykułu. W tym punkcie analiz należy jednak stwierdzić, iż gdyby spowiednik posiadał prerogatywy co do rozeznawania subiektywnego zaistnienia bądź niezaistnienia sakramentu małżeństwa, to jego decyzji o dopuszczeniu do pokuty i Eucharystii danej osoby nie da się pogodzić wprost z nauczaniem zawartym w Familiaris consortio. Trzeba ponadto nadmienić, że $\mathrm{w}$ analizowanym przypadku problem niezgodności znajduje się na płaszczyźnie dyscypliny sakramentów a nie doktryny. Jeżeli bowiem sakrament nie zaistniał (przyjmijmy w tym punkcie rozważań, że możliwe jest niezaistnienie sakramentu $\mathrm{z}$ powodu defektu po stronie nupturientów, pomimo legalności kanonicznej węzła małżeńskiego), nie ma mowy o życiu, które zaprzecza istocie Eucharystii jako rzeczywistości wyrażającej więź Chrystusa z Kościołem. Pozostaje zatem kwestia zgorszenia wiernych. Dyscyplina sakramentalna posiada istotny wpływ na świadomość ludzi wierzących na temat rozumienia małżeństwa jako nierozerwalnej świętości i rzeczywistości sakramentalnej. Dlatego też musi istnieć nieustanny namysł nad dyscypliną w korelacji do zmieniających się uwarunkowań egzystencjalnych. Właśnie taki namysł skłonił Jana Pawła II z jednej strony do podtrzymania wielowiekowej praktyki Kościoła o wykluczeniu z pełnego communio in sacris osób żyjących $\mathrm{w}$ nowych pozasakramentalnych związkach małżeńskich. $\mathrm{Z}$ drugiej zaś do ustanowienia pewnego wyjątku dla osób trwających we wstrzemięźliwości seksualnej. Jeśli papież Franciszek poszerza zakres obowiązywania tego wyjątku, to mamy do czynienia nie ze zmianą doktryny, ale dyscypliny. Nadal bowiem co do zasady rozwodnicy, żyjący w ponownych związkach, nie mogą przystępować do Stołu Pańskiego, jeśli ich stan i sposób życia obiektywnie zaprzeczają tej więzi miłości między Chrystusem i Kościołem, którą wyraża i urzeczywistnia Eucharystia. Różnica (rozwój) polega na tym, że Franciszek sugeruje, że grupa osób niewykluczonych $\mathrm{z}$ pełnego communio in sacris jest szersza.

rozumiana $w$ sensie ortodoksyjnym, w: R. ButTIGLIONE, Przyjacielska odpowiedź krytykom „Amoris Laetitia”, tłum. M. Chojnacki, Kraków 2018, s. 20-21. 


\section{NORMA PERSONALISTYCZNA JAKO FUNDAMENT RELACJI MAŁŻEŃSKIEJ O PROFILU OBLUBIEŃCZYM}

Ważnym elementem hermeneutycznego horyzontu rozumienia miłości małżeńskiej jest analiza jej oblubieńczego charakteru. Zgodnie z duchem teologii katolickiej, w którym wiara zawsze współgra z rozumem, filozoficzne analizy natury miłości małżeńskiej stanowią ważny komponent integralnego rozumienia osoby. Dlatego też poszukując najwłaściwszej interpretacji tzw. „sytuacji nieregularnych” warto pochylić się nad personalistyczną wizją małżeństwa. Wprawdzie jej fundament został zaprezentowany przez K. Wojtyłę w okresie przedpontyfikalnym w książce Miłość i odpowiedzialność, niemniej jednak jako Papież obficie czerpał z niej w swoim nauczaniu.

Punktem wyjścia refleksji na temat małżeństwa jest sama osoba, będąca w swojej konstytucji bytowej nie tylko przedmiotem, ale nade wszystko podmiotem (suppositum). Zgodnie z filozofią Wojtyły, osoba jest podmiotem myślącym, zdolnym do samostanowienia o sobie, wyznaczającym sobie cele i je realizującym. Jako takiej przysługuje jej niezbywalna godność. Przekładając to na porządek etyczny, osoby nie wolno traktować nigdy jedynie jako środka do realizacji celów innych osób. U podłoża relacji małżeńskiej leży zatem norma personalistyczna wskazująca na to, że osoba nigdy i pod żadnym pozorem nie może być sprowadzona do roli „narzędzia”. Nie może być przedmiotem „użycia”, ponieważ w takim wypadku zostaje zdeptana i pogwałcona jej godność osobowa. W miłości nie ma zatem mowy o jakiejkolwiek formie „używania” czy wykorzystania. To, co łączy małżonków, jest pozytywną „relacją” do tego dobra, które wspólnie tworzą. Rzecz jasna „relacja" ta jest dynamiczna, nie będąc czymś gotowym, rozwija się podlegając prawu wzrostu bądź degradacji w przypadku kiedy do głosu dochodzi chęć „użycia” jednej osoby przez drugą. Miłość małżeńska ze swojej istoty jest (staje się) relacją o charakterze oblubieńczym. Jej istotą jest oddanie siebie, swojego własnego ,ja” w darze drugiej wybranej osobie. Czymś daleko głębszym jest oddanie siebie aniżeli pragnienie dobra dla drugiej osoby. Jest to najpełniejsza i najradykalniejsza forma miłości. Jej wyjątkowość, właśnie owa oblubieńczość, zawiera się w tym, aby siebie dać współmałżonkowi na własność, dozgonnie i dobrowolnie. Taka forma miłości, poniekąd jej pełnia i esencja, możliwa jest do zrealizowania tylko na prawach wyłączności. To zaś jednoznacznie wskazuje na bezsporną nierozerwalność takiego układu pomiędzy ,ja” a „ty” tworzącymi wspólne „my”. Każde rozerwanie tego oblubieńczego współoddania się sobie przez małżonków sprawia, że miłość 
zamienia się w formę „użycia” drugiej osoby, a to jest sprzeczne z normą personalistyczną ${ }^{21}$.

Autentyczna miłość oblubieńcza jest ze swojej natury całościowa, ponieważ integruje różne warstwy i poziomy miłości. Relacja oblubieńcza zawiera w sobie zarówno przyjaźń, sympatię, życzliwość, pożądanie jak i upodobanie. Integruje w osobie wymiar subiektywny i podmiotowy doświadczania miłości z wymiarem obiektywnym. Spaja w jedno ruch ku swojemu wnętrzu z ruchem ku drugiej osobie. Jest to niezbędne, ponieważ miłość o profilu subiektywnym, będąca doświadczeniem przeżycia wielorakich stanów psychicznych, musi skonfrontować się z rzeczywistością obiektywizującą i wskazującą kierunek interpretacji życia psychicznego. Tym horyzontem interpretacyjnym jest prawda o człowieku jako osobie oraz moralnie wiążąca norma postępowania stojąca na straży owej prawdy. Dlatego też integracja polega również na harmonijnym zespoleniu wolności z prawdą. Zaangażowanie woli idzie w parze z przeżyciem prawdy o dobru drugiej osoby i prawdy o sobie samym jako osobie. W ten sposób ludzka wolność jak i ludzkie poznanie (rozumiane jako poszukiwanie i odnajdywanie prawdy) podporządkowane są miłości. Osoba ludzka bardziej pragnie miłości aniżeli wolności i poznania prawdy. Człowiek najbardziej staje się osobą właśnie w miłości, w której wolność zostaje ukierunkowana (poniekąd ograniczona) na umiłowaną osobę oraz w której uwaga poznawcza zostaje zwrócona nade wszystko w stronę prawdy o dobru, jakim jest oblubieniec/oblubienica. W świetle powyższych analiz należy stwierdzić z pełną stanowczością, iż wchodzenie w nowe związki o charakterze małżeńskim, charakteryzujące się wspólnym pożyciem płciowym, w czasie trwania ważnego węzła małżeńskiego prowadzi wprost do „użycia” i to obojga partnerów oraz do ich depersonalizacji. Trzeba podkreślić także i fakt, że owo „użycie” dokonuje się niezależnie od stopnia osobistej winy za rozkład wcześniejszego ważnego małżeństwa.

Obiektywny charakter „użycia”, jako czynu moralnie złego, nie przesądza jednak całkowicie o ciężarze winy i stopniu depersonalizacji, jaka mu towarzyszy. Wina zależy także od okoliczności subiektywnych. Niezwykle adekwatnie wyraża to katolicka doktryna o grzechu uwzględniająca w ocenie moralnej także stopień wolności i okoliczności czynu. Jan Paweł II opierając się na nauczaniu Soboru Trydenckiego stwierdza, że „istnieją więc akty, które jako takie, same w sobie, niezależnie od okoliczności, są zawsze wielką niegodziwością ze względu na przedmiot. Akty te, jeśli spełnione z wystarczającą świadomością i dobro-

\footnotetext{
${ }^{21}$ Zob. K. WoJTYŁA, Miłość i odpowiedzialność, Lublin 2001 (pierwsze wydanie 1960).
} 
wolnie, są zawsze ciężką winą"22. Do oceny aktu moralnego potrzebna jest zatem zarówno natura czynu, jak też świadomość i dobrowolność.

Może zatem zaistnieć sytuacja w której osoba rozwiedziona, żyjąca w nowym związku niesakramentalnym, nawraca się i pragnie uczynić zadość warunkowi wstrzemięźliwości seksualnej, ale jest przymuszana do współżycia seksualnego przez partnera bądź inne okoliczności. Chociaż materia takiego czynu jest poważna, to nie ma pełnej zgody podmiotu na akt. Według znanego etyka i znawcy nauczania K. Wojtyły/Jana Pawła II - Rocco Buttiglione w takich przypadkach, spowiednik mógłby udzielić rozgrzeszania i dopuścić do pełni sakramentów, ponieważ nie wystąpiły wszystkie wymagane okoliczności pozwalające uznać akt za ciężką winę (wystarczająca świadomość i dobrowolność $)^{23}$. Niemniej jednak osoba taka podejmując współżycie seksualne, nawet bez pełnej zgody i świadomości, wchodzi w relację o charakterze utylitarystycznym, w którym partnerzy seksualni dokonują wzajemnego „urzeczowienia". Należy przy tym także pamiętać, że akty o charakterze ściśle relacyjnym łączą wokół jednej natury przedmiotowej aktu dwa światy podmiotowe (osoby). W związku z tym, nawet jeśli jeden podmiot cechuje się ograniczoną odpowiedzialnością subiektywną za czyn, nie można zapominać o drugim podmiocie. Istnieje współodpowiedzialność za drugiego człowieka, zwłaszcza podczas popełniania aktów wybitnie wspólnotowych. Nie może zostać zaakceptowana jako satysfakcjonująca sytuacja, w której jeden podmiot, wskutek moralnej oceny subiektywnych uwarunkowań czynu, pozostaje w pewien sposób usprawiedliwiony, a drugi podmiot ponosi pełną odpowiedzialność za czyn. Oczywiście takie sytuacje się zdarzają. Jednakże należy zawsze dążyć do wyeliminowania obiektywnego zła. Złem jest w tej sytuacji współżycie obiektywnie cudzołożne. Dlatego też, dla dobra obojga partnerów, musi zostać ono porzucone. Droga nawrócenia, która może być rozciąnnięta w czasie, musi jednak w tej sytuacji nieustannie dążyć do wstrzemięźliwości, która pozwoli zapobiec obiektywnemu nieuporządkowaniu relacji i wzajemnemu „urzeczowieniu”.

Analizując przypadek, w którym osoba jest subiektywnie przeświadczona o niezaistnieniu pierwszego sakramentalnego małżeństwa, uwzględniając wszystkie poczynione wcześniej w tym kontekście założenia, należy stwierdzić, że osoba taka jest moralnie odpowiedzialna za „urzeczowienie” siebie i partnera w pierwszym związku i może (choć nie musi) być odpowiedzialna za „urzeczowienie” siebie i partnera w drugim związku. Jeżeli pierwszy zwią-

\footnotetext{
22 JAN PAWEe II, Adhortacja „Reconciliatio et paenitentia”, Rzym 1984, nr 17.

${ }^{23}$ Por. R. ButTiglione, Przyjacielska odpowiedź krytykom „Amoris Laetitia”, s. 126-132.
} 
zek nie był relacją o charakterze oblubieńczym, to dochodził tam do głosu egoizm i utylitaryzm. Każdy akt seksualny był zatem moralnie niegodziwy, ponieważ sprzeciwiał się naturze miłości traktując partnera jako środek do celu. Oczywiście można mówić, że w tym związku nie było wystarczającej dojrzałości w decyzji o zawarciu węzła małżeńskiego i świadomości tego, czym jest miłość w swoim oblubieńczym charakterze. Jednakże odpowiedzialność za rozpad pierwszego małżeństwa spoczywa na partnerach proporcjonalnie do ich własnego utylitarystycznego nastawienia będącego zaprzeczeniem miłości oblubieńczej. W takiej sytuacji, jeśli drugi związek - cywilny - jest zbudowany w oparciu o miłość o charakterze oblubieńczym, może nie dochodzić w nim do „urzeczowienia” i depersonalizacji.

\section{OSĄD SUMIENIA A OBIEKTYWNA WARTOŚĆ CZYNU}

Niezwykle istotnym zagadnieniem w procesie poszukiwania właściwego horyzontu interpretacyjnego sytuacji osób żyjących stale na sposób małżeński (more uxorio) z osobą, która nie jest prawowitą małżonką albo prawowitym mężem, jest kwestia osądu sumienia, a ściślej relacji pomiędzy osądem sumienia a obiektywną wartością czynu.

W Amoris laetitia papież Franciszek, powołując się na nauczanie obecne w tradycji Kościoła podkreśla, że nie wszyscy żyjący w tzw. „sytuacji nieregularnej” egzystują w stanie grzechu śmiertelnego i pozbawieni są łaski uświęcającej ${ }^{24}$. Ojciec Święty, powołując się na Katechizm Kościoła Katolickiego przypomina także, że niektóre okoliczności moga zmniejszać odpowiedzialność moralną za popełniony czyn, a negatywny osąd moralny czynu nie musi zawsze oznaczać winy konkretnej osoby z uwagi na okoliczności ograniczające odpowiedzialność podmiotu za popełniony akt ${ }^{25}$. W związku z tym - jak zauważa Papież - „możliwe jest, że pośród pewnej obiektywnej sytuacji grzechu osoba, która nie jest subiektywnie winna albo nie jest w pełni winna, może żyć w łasce Bożej, może kochać, a także może wzrastać w życiu łaski i miłości, otrzymując w tym celu pomoc Kościoła"26.

Nie budzi wątpliwości - z punktu widzenia nauczania Jana Pawła II - zastosowanie powyższych analiz do sytuacji osób, które na swojej drodze nawrócenia

\footnotetext{
${ }^{24}$ Por. FrancisZeK, Adhortacja „Amoris laetitia”, nr 301.

25 Por. tamże, nr 302.

26 Tamże, nr 305.
} 
decydują się żyć z sobą jak „brat z siostrą”. Natomiast interpretacja zmierzająca do dopuszczenia do stołu Eucharystycznego osób, które w nowych związkach nie podejmują wstrzemięźliwości seksualnej, ujawnia się jako niedopuszczalna. Świadczy o tym jednoznaczne stwierdzenie Jana Pawła II: „Pojednanie w sakramencie pokuty - które otworzyłoby drogę do komunii eucharystycznej - może być dostępne jedynie dla tych, którzy żałując, że naruszyli znak Przymierza i wierności Chrystusowi, są szczerze gotowi na taką formę życia, która nie stoi w sprzeczności z nierozerwalnością małżeństwa. Oznacza to konkretnie, że gdy mężczyzna i kobieta, którzy dla ważnych powodów - jak na przykład wychowanie dzieci - nie mogąc uczynić zadość obowiązkowi rozstania się, „postanawiają żyć w pełnej wstrzemięźliwości, czyli powstrzymywać się od aktów, które przysługują jedynie małżonkom"27.

Zachodzi zatem pytanie, czy stanowisko Jana Pawła II jest ,,jedynie czasowe" i czy można, pozostając $w$ zgodzie $\mathrm{z}$ zasadami sakramentologii oraz katolickiej teologii moralnej, otworzyć drogę do Stołu Pańskiego także tym osobom, które decydują się na współżycie w nowym związku, z uwagi na to, że w swoim sumieniu są subiektywne przeświadczone o braku winy za rozpad sakramentalnego małżeństwa?

Zdaniem kardynała Müllera oraz Buttiglione - można w pewnych okolicznościach i z zachowaniem drogi rozeznania, ponieważ istnieją ku temu przesłanki teologicznomoralne, a stanowisko Jana Pawła II jest ,jedynie” określeniem dyscypliny kościelnej $\mathrm{w}$ takich przypadkach ${ }^{28}$. Inaczej na postawione pytanie odpowiedział kardynał Ratzinger. W Liście do biskupów Kościoła katolickiego na temat przyjmowania Komunii świętej przez wiernych rozwiedzionych żyjacych w nowych zwiazkach ówczesny prefekt Kongregacji Nauki Wiary stwierdził, że taka sytuacja nie jest możliwa. Człowiek nie może przyznać swojemu sumieniu prawa do decydowaniu na podstawie swojego przekonania o istnieniu bądź nieistnieniu poprzedniego małżeństwa i o ważności nowego związku ${ }^{29}$. Ponadto „zgoda, dzięki której zaistniało małżeństwo, nie jest zwyczajną decyzją prywatną, gdyż stawia każdego z małżonków i oboje razem w specyficznej sytuacji kościelnej i społecznej. Dlatego też sąd sumienia na temat własnej sytuacji małżeńskiej nie dotyczy jedynie bezpośredniego stosunku pomiędzy człowiekiem i Bogiem, tak jak gdyby można było pominąć pośrednictwo Kościoła, które obejmuje również przepisy kanoniczne

27 JAN PAWE€ II, Adhortacja „Familiaris consortio”, nr 84.

28 Zob. R. Buttiglione, Przyjacielska odpowiedź, krytykom „Amoris Laetitia”.

29 Por. J. RATZINGER, List do biskupów Kościoła katolickiego na temat przyjmowania Komunii św. przez wiernych rozwiedzionych żyacych w nowych zwiazkach, Rzym 1994, nr 7. 
obowiązujące w sumieniu. Nieuznawanie tego istotnego aspektu w praktyce oznaczałoby zaprzeczenie faktu, że małżeństwo istnieje jako rzeczywistość Kościoła, to znaczy jako sakrament"30.

Profesor Buttigione, zapewne znając powyższe stanowisko Ratzingera, usiłuje wykazać, że istnieje rozwiązanie, w którym osoba subiektywnie przeświadczona o nieważności pierwszego małżeństwa mogłaby zweryfikować swoje przekonanie opierając się na osądzie Kościoła. Włoski etyk po pierwsze zachęca spowiedników do przedstawienia takim osobom możliwości, jakie daje prawo kanoniczne. Orzecznictwo sądów kościelnych w takich przypadkach zostało zresztą przez papieża Franciszka znacząco usprawnione i przyspieszone. Istnieja jednak sytuacje - przekonuje Buttigione - w których z różnych względów nie da się dowieść przed sądem nieważności małżeństwa pomimo subiektywnego przekonania osoby o jego nieważności. W takich przypadkach dochodzi do sytuacji, w której nie zaistniał sakrament, ale istnieje małżeństwo jako fakt publiczny i kościelny. Naruszenie porządku publicznego i kościelnego wymaga kary i zadośćuczynienia, ale - pyta dalej włoski etyk - czy wykluczenie z sakramentów nie jest sankcją nadmierną? W sytuacji, w której po rozpadzie pierwszego małżeństwa i wstąpienia w drugi związek cywilny, osoby (bądź osoba) przeżyją nawrócenie - zdaniem Buttigione - można porównać do tej w Kościele pierwotnym, w którym małżeństwo zawarte pomiędzy chrześcijaninem a poganinem mogłoby być rozwiązane ze względu na ochronę wiary (przywilej Pawłowy i Piotrowy). Czasy współczesne są poniekąd porównywalne do tych pierwotnych, tyle że dziś neopoganie często są ochrzczeni. Autor książki Przyjacielska odpowiedź krytykom „Amoris Laetitia” postuluje, aby spowiednik w imieniu Kościoła, rozeznając każdorazowo sytuację, mógł dopuścić osobę subiektywnie przeświadczoną o niezaistnieniu pierwszego sakramentalnego małżeństwa do pełni sakramentów $^{31}$. Takie rozwiązanie jest pozbawione krytykowanego przez Ratzingera subiektywizmu, w imię którego osoba prywatna mogłaby rościć sobie prawo do decydowania o zaistnieniu bądź nie małżeństwa. Oczywiście o tym czy sakrament zaistniał czy nie ostatecznie może zawyrokować jedynie Kościół, który posiada właściwe mu pośrednictwo sakramentalne i władzę związywania i rozwiązywania.

W tym punkcie rozważań należy postawić fundamentalne pytanie, czy i pod jakimi warunkami można uznać, że w sytuacji prawnokanonicznego

\footnotetext{
30 Tamże, nr 8.

${ }^{31}$ Por. R. Buttiglione, Przyjacielska odpowiedź krytykom „Amoris Laetitia”, s. 50-53.
} 
i publicznego zawiązania węzła małżeńskiego nie dochodzi do zaistnienia sakramentu małżeństwa? Kardynał Müller czy Buttigione, choć wielokrotnie postulują możliwość dopuszczenia po rozeznaniu do pełnej communio in sacris przynajmniej niektórych osób znajdujących się w takiej sytuacji, to nie podejmują głębszej teologiczno-sakramentalnej refleksji nad możliwością niezaistnienia sakramentu małżeństwa w sytuacji, w której został on zawarty w sposób ważny i wiążący ex opere operato. Samo w sobie stanowi to poważny defekt ich stanowiska, bowiem nie udowadniają, że taki stan swoistego „rozdwojenia sakramentalnego” jest w ogóle możliwy.

Teologia systematyczna o profilu personalistycznym w strukturze każdego sakramentu wyróżnia cztery współelementy: materię i formę sakramentu, prozopoiczne osadzenie znaku sakramentalnego w szafarzu - przynajmniej $\mathrm{w}$ formie intencji sprawienia sakramentu - a także osobę przyjmującego z całym jej światem. Przyjrzyjmy się bliżej roli osoby przyjmującej sakrament. Jak postuluje Czesław Stanisław Bartnik sakrament nie dokona się, jeśli osoba przyjmującego będzie poza „dialogiem z szafarzem”. Chodzi tu o sytuację nieprzyjęcia bądź negacji „świętego znaku”, jaki jest wobec niej czyniony. Ważny jest wyraźny brak woli przyjęcia. W sytuacji chrztu niemowląt, podmiot sakramentu nie ma woli przyjęcia tegoż świętego znaku, a mimo to sakrament jest ważny. Dzieje się to po części na mocy antycypowania woli dziecka przez rodziców. Sakramenty bowiem są zawsze zawieszone w szerszym kontekście międzyosobowym. Wola dziecka, wraz ze wzrostem jego świadomości, powoduje coraz pełniejsze ożywianie i owocowanie chrztu. Nie występuje tu jednak żadna negacja sakramentu czy choćby sceptycyzm w stosunku do tego, co wyraża ${ }^{32}$.

W sytuacji małżeństwa wymagana jest nie tylko wyraźna zgoda na przyjęcie małżeństwa jako instytucji prawa naturalnego, ale także przynajmniej habitualna, wyczytywana z życia podmiotu zgoda na jego ściśle chrystologiczny i eklezjologiczny (oblubieńczy) charakter. Bartnik zauważa, że jeśli wystąi brak zgody na sakrament, to ten nie zaistnieje. Odwołuje się do nauczania papieża Inocentego III, który wyraźnie stwierdził, że w przypadku kiedy ktoś nie wyraził zgodny na chrzest, ten jest nieważny. W związku $\mathrm{z}$ tym kiedy brak intencji przyjęcia sakramentu, ten nie dokonuje się w osobie z uwagi na brak podmiotowego dopełnienia. Nie mniej jednak kiedy „była intencja szafarza, a nie było intencji przyjmującego, to przy owych czterech sakramentach (chrztu, bierzmowania, kapłaństwa i małżeństwa) aktu sakra-

\footnotetext{
32 Por. Cz.S. BARTnIK, Dogmatyka katolicka, t. 2, Lublin 2010, s. 595-596.
} 
mentalnego się nie powtarza, bo były one wykonane in persona Christi i sa obietnica z nieba, której Bóg nie cofa. Dlatego po pojawieniu się u przyjmującego wyraźnej wiary i intencji oraz po usunięciu ewentualnie innych przeszkód sakramenty te realnie się dokonują oraz uzyskują owocność i skuteczność, czyli charakter sakramentalny sprawia, że one „ożywają"33.

Światło na analizowany w artykule problem rzuca także kwestia ważności i legalności sakramentów. Zdaniem Bartnika ważność i legalność sakramentów nie została jeszcze zbadana teologicznie w sposób satysfakcjonujący. W teologii prawosławnej obie kategorie są de facto ze sobą utożsamione, natomiast myśl katolicka je wyraźnie rozdziela. Nielegalność - czyli sprawowanie sakramentu z naruszeniem prawa kościelnego - unieważnia sakramenty związane $\mathrm{z}$ władzą kościelną, ale nie unieważnia tych wyciskających znamię sakramentalne ${ }^{34}$. Także sakramenty, sprawowane legalnie, mogą być nieważne z przyczyn stojących po stronie podmiotu. Nieważność sakramentu małżeństwa mogłaby zachodzić np. w przypadku wykluczenia posiadania potomstwa. Zanegowanie tego fundamentalnego celu stawia pod znakiem zapytania całą międzyosobową strukturę, jaką jest małżeństwo. Przyczyną stojącą po stronie podmiotu mógłby być także brak wiary.

Innym przypadkiem jest przystępowanie do sakramentów w stanie grzechu śmiertelnego. Zdaniem Bartnika „w przypadkach sakramentów z charakterem sakramentalnym, podobnie jak w sprawie braku wiary, skoro następuje potem doskonały żal za grzechy lub/i spowiedź - sakramenty te „ożywaja” ${ }^{35}$. Natomiast sakramenty nie wywierające znamienia nie „ożywają”. Jak w związku z tym interpretować sytuację sakramentalnego małżeństwa, które wywiera znamię sakramentalne jedynie analogicznie do chrztu, bierzmowania czy święceń? Co w przypadku rozpadu związku zawartego, choćby z zachowaniem ważnej kanonicznej formy, ale $w$ grzechu śmiertelnym i/lub bez wiary i/lub z wykluczeniem fundamentalnych celów małżeństwa? Trzeba zgodzić się z Bartnikiem, że kwestia ważności i legalności sakramentów wymaga jeszcze dopracowania. Korzystając jednak z przesłanek teologicznych, zaprezentowanych powyżej, należy uznać za możliwą sytuację w której sakrament nie zaistniał z powodu defektu po stronie osoby przyjmującej. W związku z tym należy uznać za możliwą sytuację, w której osoba przystępuje do sakramentu

\footnotetext{
33 Tamże, s. 602.

${ }^{34}$ Por. tamże, s. 604-605.

35 Tamże, s. 641.
} 
małżeństwa, ale pomimo ważnej formy kanonicznej, z uwagi na defekty w przestrzeni ex opere operantis małżeństwo nie zaistniało.

Niezbędnym dopełnieniem dotychczasowych rozważań jest teologiczno-etyczna analiza sumienia, jego prerogatyw oraz powiązania z obiektywną wartością czynu. Sobór Watykański II poucza, że „w głębi sumienia człowiek odkrywa prawo, którego sam sobie nie nakłada, lecz któremu winien być posłuszny i którego głos wzywający go zawsze tam, gdzie potrzeba, do miłowania i czynienia dobra, a unikania zła, rozbrzmiewa w sercu nakazem: czyń to, tamtego unikaj. Człowiek bowiem ma w swym sercu wypisane przez Boga prawo, wobec którego posłuszeństwo stanowi o jego godności i według którego będzie sądzony (por. Rz 2,14-16)"36. Sumienie nie ustanawia prawa, ale jako sąd praktyczny aplikuje nakaz teoretycznej normy obiektywnej do konkretnej sytuacji, w której osoba dokonuje czynu. Praktyczny osąd sumienia, któremu człowiek winien posłuszeństwo, ujawnia w swojej wewnętrznej konstytucji łączność wolności z prawdą. Jeżeli owa łączność zostaje rozerwana, sąd sumienia staje się błędny ${ }^{37}$. Jak poucza Sobór Watykański II zdarza się, że błędny osąd sumienia wypływa z niezawinionej i niepokonalnej niewiedzy. Wówczas nie traci on swojej godności i obowiązywalności w danej chwili. Jednakże w sytuacji, w której człowiek zaniedbuje formację sumienia czy też egzystuje w stanie permanentnego grzechu, sumienie ulega zaślepieniu i traci swoją godnośćc ${ }^{38}$.

Na podstawie soborowego rozumienia sumienia nie można mówić o braku winy moralnej w sytuacji braku formacji sumienia. Nie mogą zatem osoby, które niewiele dbały o prawość swojego sumienia, tłumaczyć się osądem własnego błędnie uformowanego sumienia jako kryterium do rozstrzygania tak ważności sakramentu jak własnej winy moralnej za jego rozpad. Podobnie nie zwalnia osoby z odpowiedzialności za rozpad małżeństwa nawet niewiedza niepokonalna. Jak tłumaczy Jan Paweł II: „,nie wolno jednak nigdy mylić błędnego „subiektywnego" mniemania o dobru moralnym z prawdą „obiektywną", ukazaną rozumowi człowieka jako droga do jego celu, ani też twier-

\footnotetext{
${ }^{36}$ SOBÓR WATYKAŃSKI II, Konstytucja duszpasterska o Kościele w świecie wspótczesnym „Gaudium et spes”, Rzym 1965, nr 18.

37 Por. Jan PAweŁ II, Encyklika „Veritatis splendor”, Rzym 1993, nr 60-61.

${ }^{38}$ Por. SoBÓR WATYKAŃSKI II, Konstytucja duszpasterska o Kościele w świecie wspótczesnym „Gaudium et spes”, nr 18.
} 
dzić, że czyn dokonany pod wpływem prawego sumienia ma taką samą wartość jak czyn, który człowiek popełnia, idąc za osądem sumienia błędnego. Zło dokonane $\mathrm{z}$ powodu niepokonalnej niewiedzy lub niezawinionego błędu sumienia może nie obciążać człowieka, który się go dopuścił, ale także w tym przypadku nie przestaje być złem, nieporządkiem w stosunku do prawdy o dobru. Co więcej, dobro nierozpoznane nie przyczynia się do wzrostu moralnego osoby, która je czyni, gdyż jej nie doskonali i nie pomaga jej zwrócić się ku najwyższemu dobru" ${ }^{39}$.

W sytuacji osób żyjących stale na sposób małżeński (more uxorio) z partnerem, który nie jest prawowitą małżonką albo prawowitym mężem, nie wolno podejmować współżycia płciowego zarezerwowanego jedynie dla małżeństwa. Żadne okoliczności nie mogą uzasadnić działania wewnętrznie złego. Jak naucza Jan Paweł II „,mamy bowiem do czynienia z grzechem śmiertelnym także wtedy, gdy człowiek świadomie i dobrowolnie, dla jakiejkolwiek przyczyny, wybiera coś, co jest poważnym nieporządkiem. W rzeczy samej taki wybór już zawiera w sobie wzgardę Bożym przykazaniem, odrzucenie miłości Boga do ludzkości i całego stworzenia: człowiek sam się oddala od Boga i traci miłość" 40 . Intencja podmiotu nie może przesądzać o ostatecznym dobru lub złu moralnym danego czynu. Pierwszym i decydującym elementem oceny etycznej danego czynu jest zawsze jego przedmiot. On także definitywnie określa czy dany akt działania można przyporządkować ostatecznemu celowi oraz dobru człowieka, którym jest sam Bóg ${ }^{41}$. Osoby, których sakramentalny związek małżeński zaistniał, a potem został nieodwracalnie zniszczony, nie moga podejmować współżycia seksualnego z partnerem w nowym związku, z uwagi na trwanie wcześniejszego węzła małżeńskiego. Nawet sytuacja, w której osoba jest subiektywnie przeświadczona, że rozpad małżeństwa sakramentalnego został spowodowany przez współmałżonka, nie powoduje, że sakrament wcześniej zawarty zanika. W związku z tym każde współżycie płciowe jest grzechem śmiertelnym. Trudno bowiem w takim przypadku mówić o braku świadomości bądź o nieumiejętności zastosowania ogólnej normy w konkretnej sytuacji życiowej. Wszakże św. Tomasz z Akwinu uważał, że człowiek może, znając ogólne zasady prawa naturalnego, wyciągać $\mathrm{z}$ nich błędne wnioski w konkretnych sytuacjach, to jednak trudno utrzymywać, że ktoś pouczony o naturze małżeństwa sakramentalnego przed jego

\footnotetext{
39 JAN PAWE€ II, Encyklika „Veritatis splendor”, nr 63.

40 Jan PaWeE II, Adhortacja „Reconciliatio et paenitentia”, Rzym 1984, nr 17.

${ }^{41}$ Por. JAN PAWEE II, Encyklika „Veritatis splendor”, nr 79.
} 
zawarciem mógłby mieć niezawiniona niewiedzę na temat nierozerwalności małżeństwa, jak sugeruje Butiiglione ${ }^{42}$.

Nie można także przyjąć tłumaczenia, iż w „sytuacjach nieregularnych” współżycie może być ,tolerowane" bądź w jakiś sposób prowadzić do dobra ze względu na intencję podmiotu (np. współżycie podejmowanie w celu trwania nowego związku cywilnego, choćby dla dobra potomstwa). Istotne światło na tę kwestię rzuca etyczna analiza czynów „,wewnętrznie złych” (intrinsece malum). Wielcy Doktorowie Kościoła, jak choćby św. Augustyn i św. Tomasz z Akwinu, a za nimi Tradycja katolicka, nauczają, że jeśli czyny są wewnętrznie złe, dobra intencja nie może ani ich usprawiedliwić, ani tym bardziej sprawić, że przestaną być wewnętrznie złe i grzeszne. Taki sam punkt widzenia można odnaleźć w $\mathrm{Ka}$ techizmie Kościoła Katolickiego (1750-1756). Jan Paweł II także stwierdza, że: „okoliczności lub intencje nie zdołają nigdy przekształcić czynu ze swej istoty niegodziwego ze względu na przedmiot w czyn „subiektywnie” godziwy lub taki, którego wybór można usprawiedliwić"43.

Nieco inna jest sytuacja osoby, która będąc od długiego czasu w nowym niekanonicznym związku, często tworząc nową rodzinę z potomstwem, nawraca się i pragnie żyć w wstrzemięźliwości seksualnej, ale nie udaje jej się to, czy to z powodu aktualnej słabości woli, czy to mocnej presji partnera z nowego związku. W takich przypadkach moga wystąpić - jak sugeruje Buttiglione - pewne okoliczności łagodzące zdolne sprawić, że grzech, choć ciężki co do materii, nie staje się śmiertelnym ${ }^{44}$. Należy jednak zawsze pamiętać, że czyn taki jest niegodziwy. Wydaje się, że spowiednik, idąc za wskazaniami papieża Franciszka, mógłby po odpowiednim rozeznaniu dopuścić taką osobę do Stołu Pańskiego. Jeśli grzech współżycia cudzołożnego rodziłby się ze słabości osoby, która deklarowałaby skruchę i chęć zaprzestania współżycia, można by potraktować ją podobnie jak osoby będące pod wpływem nałogu. Jeśli zaś do współżycia nakłaniałby partner z nowego związku, wtenczas nie byłby to czyn dobrowolny.

Ogólnie rzecz ujmując, co do argumentacji natury teologicznomoralnej, należy zgodzić się z twierdzeniem kardynała Müllera, że w sytuacji, w której nie zaistniał grzech śmiertelny, dana osoba (osoby) może zostać dopuszczona do pełnego communio in sacris ${ }^{45}$. Jednakże takie sytuacje mogą wystąpić

\footnotetext{
42 Por. R. Buttiglione, Przyjacielska odpowiedź krytykom „Amoris Laetitia”, s. 72-75.

43 JAN PAWEE II, Encyklika „Veritatis splendor”, nr 81.

${ }^{44}$ Por. R. ButTiglione, Przyjacielska odpowiedź krytykom „Amoris Laetitia”, s. 159-160.

${ }^{45}$ Por. G.L. MüLler, Przedmowa. Dlaczego adhortacja „Amoris Laetitia” może i powinna być rozumiana $w$ sensie ortodoksyjnym, s. 12.
} 
jedynie wtedy, gdy dana osoba z całych sił pragnie żyć tak, aby nie naruszać oblubieńczego charakteru sakramentu Eucharystii. W związku z tym musi dążyć do zaprzestania współżycia dopóki trwa związek kanoniczny. W przeciwnym razie zostaje podeptany, jak to ujął Jan Paweł II, obiektywny wymiar sakramentu Eucharystii, będący nierozerwalnym przymierzem Chrystusa z Kościołem, podobnie jak małżeństwo.

Jeśli przyjąć powyższe rozważania, to podsumowując można powiedzieć, że różnica w podejściu do tzw. „sytuacji nieregularnych” zależy od tego, czy w pewnych okolicznościach, w jakich znajduje się podmiot, biorąc pod uwagę tradycyjną naukę Kościoła na temat grzechu i sakramentów, można pomimo obiektywnego zniszczenia pierwszego legalnie zawartego małżeństwa, dopuścić do pełni sakramentów czy też nie. Jan Paweł II uznał, że w pewnych szczególnych sytuacjach „tak”, ale pod warunkiem wstrzemięźliwości seksualnej. Franciszek zdaje się jeszcze rozszerzać tę perspektywę, jednakże nie określając jej wystarczająco jasno. Prawdopodobnie można w to włączyć również niektóre osoby, które są w sumieniu pewne co do tego, że ich pierwsze małżeństwo nie zaistniało. Być może również i takie, które pragną żyć we wstrzemięźliwości seksualnej, ale w danej chwili nie mogą tego uczynić, czy to ze względu na słabość woli (jak w nałogu), czy też z uwagi na presję otoczenia (partnera). Są to jednak ,tylko” pewne dociekania teologiczne ukazujące pewien horyzont interpretacyjny, które rodzą się w obliczu braku jasnego wykładu od strony Magisterium.

\section{ROZWÓJ DOKTRYNY A „ZMIANA PARADYGMATU”}

Rozumienie doktryny w Kościele ulega nieustannemu rozwojowi. Jest to kwestia nie pozostawiająca wątpliwości. Rodzi jednak problem, jak pogodzić uprawniony i potrzebny rozwój rozumienia Objawienia, którego dawcą i inspiratorem jest Duch Święty, ze współczesną kulturą intelektualną człowieka. Jest oczywistością, że wiara także jako zespół twierdzeń i norm musi mieć realny wpływ na życie człowieka. W związku z tym nie można zadowolić się jedynie sytuacją, w której formuły wiary staną się jakimś archaicznym reliktem przeszłości, niezrozumiałym dla współczesnych ludzi, a przez to niemożliwym do przełożenia na życie. $Z$ drugiej jednak strony - jak słusznie poucza Międzynarodowa Komisja Teologiczna - „Teologia współczesna o ukierunkowaniu hermeneutycznym szuka możliwości rzucenia pomostu między tradycją dogmatyczną i myślą współczesną, stawiając kwestię sensu i znaczenia dogmatów dla człowieka dzisiejszego. W ten sposób jednak oddziela się poszcze- 
gólne formuły dogmatyczne od ich powiązania z Paradosis i izoluje się je od wiary przeżywanej przez Kościół. Następuje więc ,urzeczowienie” dogmatu; ponadto, stawiając w centrum problem znaczenia praktycznego, egzystencjalnego lub społecznego dogmatu, traci się z oczu kwestię jego prawdy. To zastrzeżenie jest tak samo ważne $\mathrm{w}$ tej sytuacji, gdy dogmat jest uważany jedynie za kwestię umowną, można powiedzieć - rozważany w jego funkcji, jaką byłoby tylko sprecyzowanie języka eklezjalnego, koniecznego dla jedności, ale ze swej natury prowizorycznego i podlegającego poprawkom. Tym sposobem dogmat nie jest już rozważany w jego funkcji koniecznego pośrednictwa dla prawdy objawionej" ${ }^{46}$.

Natura uprawnionego i ortodoksyjnego rozwoju wiary polega na tym, że „Kościół nie dodaje niczego nowego (non nova) do Ewangelii, ale głosi nowość Chrystusa za każdym razem w nowy sposób (noviter). Włącza do swojego skarbca za każdym razem nowe elementy pozostające $\mathrm{w}$ harmonii z tymi starożytnymi" ${ }^{47}$. W związku z tym, kiedy ma się do czynienia z ugruntowaną kościelną doktryną, jak ma to miejsce w przypadku nauczania na temat małżeństwa jako sakramentu, nie można oczekiwać jakiejkolwiek „zmiany paradygmatu". Ortodoksyjny rozwój prawd wiary może i musi cechować się „,jedynie” walorem lepszego wyjaśnienia danego misterium wiary chrześcijańskiej.

Nauczanie na temat sakramentalnego małżeństwa, jak każda inna doktryna Kościoła, może być interpretowana jedynie w wierze. Wynika to z jej wewnętrznej konstytucji. Dogmat (w sensie szerokim jak i ścisłym) jest możliwością (łaską) uczestnictwa ludzkości w odwiecznej komunikacji z Ojcem przez Syna w Duchu Świętym. Dlatego też formuły wiary, w tym nauczanie o sakramentalnym małżeństwie, posiadają potrójną naturę hermeneutyczną naświetlającą odwieczną i niezmienną prawdę o samym Bogu i sposobach jego samoudzielania się człowiekowi, która bez tego pośrednictwa pozostaje dla człowieka na ziemi niedostępna. Po pierwsze: formuły dogmatyczne powinny być postrzegane jako to verbum rememorativum (słowo przypominające). To swoista anamneza wielkich dzieł Bożych (magnalia Dei), toteż muszą one zarówno wychodzić od Pisma Świętego, jak i prowadzić do jego pogłębionego rozumienia. W tym procesie muszą uwzględniać także Tradycję według prawideł analogia fidei. Po drugie: prawdy wiary winny być interpretowane jako verbum demonstrativum (słowo zapewniające). Nie mówią one

\footnotetext{
46 Międzynarodowa Komisja TeOlogiczna, Interpretacja dogmatów, nr A.II.2.

47 Tamże, nr B.III.1.
} 
jedynie o dziełach zbawczych z przeszłości, lecz są skuteczne także tu i teraz. Jest to niezwykle ważny element hermeneutyki prawd wiary w przypadku nauki o sakramentalnym małżeństwie, ponieważ dotyczy ono w sposób najbardziej bezpośredni i egzystencjalny człowieka w jego ziemskim życiu. Słowo wiary, opisujące rzeczywistość miłości międzyludzkiej w jej oblubieńczym wymiarze, jest nośnikiem prawdy zbawczej dotyczącej drogi człowieka na której spełnia się on jako byt osobowy jak też zmierza ku swemu ostatecznemu przeznaczeniu, czyli samemu Bogu. Po trzecie: formuły wiary to także verbum prognosticum (słowo zapowiadające). Traktują one o przyszłym losie człowieka jako osoby. Dają świadectwo o rzeczywistości zbawienia eschatologicznego zarówno w wymiarze przyszłym (eschatologia niedokonana) jak i egzystencjalnym (eschatologia dokonana) ${ }^{48}$.

W obliczu powyższych uwag nie można uznać za ortodoksyjną hermeneutykę nauczania o sakramentalnym małżeństwie, która ogołaca przekaz wiary z któregokolwiek elementu dla niego konstytutywnego. Wydaje się zatem, że pozwolenie na przystąpienie do Stołu Pańskiego osób żyjących w tzw. „sytuacji nieregularnej" wymaga zaakceptowania przez nich w swoim życiu takiej formy wspólnoty, która nie będzie sprzeczna z teologiczną wymową sakramentu Eucharystii, którą przyjmują. Należy zaszczepić w nich żywą świadomość, że sakrament małżeństwa jak i Eucharystia to verbum rememorativum, które z jednej strony pokazują prawdę o totalnej miłości Chrystusa do człowieka, z drugiej zaś wskazują na ogromna „,cenę”, jaką poniósł w imię tej miłości Chrystus. Przypomina także o jasnej i jednoznacznej woli samego Zbawiciela, który nauczał, że co Bóg złączył, człowiek niech nie rozdziela. Jednocześnie nauka o małżeństwie sakramentalnym jest słowem zapewniającym, że Bóg jest z człowiekiem w każdej sytuacji jego życia i ma moc zbawienia, o ile człowiek przylgnie do Niego całym sercem i wsłucha się w Jego głos. Sytuacja, w której to jedynie wewnętrzny głos sumienia miałby decydować o rozerwaniu małżeńskiego węzła z uwagi na przytłaczające okoliczności życia, de facto jest niewiarą w to, że Bóg błogosławiąc małżeństwu sakramentalnemu sam staje się gwarantem jego trwania i bycia przestrzenią spełnienia się człowieka jako osoby w życiu doczesnym i wiecznym. Słowo wiary w swoim hermeneutycznym oddziaływaniu na człowieka jest także verbum prognosticum. Stanowi zapowiedź spełnienia człowieka w wymiarze eschatologicznym. Nauka o sakramentalności małżeństwa, mówiąca o związku mężczyzny i kobiety jako rzeczywistości nierozerwalnej i komunijnej, zapowiada

\footnotetext{
${ }^{48}$ Por. tamże, nr B.III.2.
} 
wiecznotrwałą komunię pomiędzy Bogiem a człowiekiem. Sakramentalność stanu małżeńskiego utwierdza $\mathrm{w}$ przekonaniu, że życie w wymiarze eschatologicznym będzie, przy zachowaniu wszystkich praw analogii języka ludzkiego wobec tajemnicy Boga, w znaczący sposób podobne do komunii, jaka zachodzi pomiędzy mężem i żoną w łasce sakramentu. Niedopuszczalne jest jakiekolwiek rozmycie teologicznego rozumienia sakramentu, choćby bez istotnej zmiany doktryny, ponieważ powoduje to utratę waloru profetycznego małżeństwa. Rozmyciem takim jest sytuacja, w której obiektywny stan rozerwania przez człowieka węzła sakramentalnego byłby pominięty lub zastąpiony jedynie subiektywną oceną sumienia. Do takiego stanu rzeczy nie wolno dopuścić w praktyce duszpasterskiej. Jednakże sytuacja, analizowana w niniejszym tekście, w której osoba subiektywnie przeświadczona o niezaistnieniu sakramentu, znajduje potwierdzenie takiego stanu rzeczy u swojego duszpasterza, nie musi powodować rozmycia teologicznego charakteru małżeństwa jako sakramentu. Trzeba zadbać $\mathrm{w}$ takich przypadkach o uniknięcie zgorszenia pośród wiernych, aby nie powodować w ich sumieniach zamętu co do natury małżeństwa.

\section{ZAKOŃCZENIE}

Właściwa interpretacja przekazu wiary, dotyczącego małżeństwa jako rzeczywistości sakramentalnej oraz relacyjnej, to niezwykle istotne zadanie. Każde pokolenie teologów musi je podjąć uwzględniając zarówno trwałą wartość prawdy objawionej jak i dbając o ożywczą wartość przekazu wiary w zmieniającej się sytuacji społeczno-kulturowej. Nauczanie papieża Franciszka na temat tzw. „sytuacji nieregularnych”, zawarte w adhortacji Amoris laetitia, jest właśnie taką próbą „interpretacji aktualizującej” dobrej nowiny o małżeństwie. Aby mogło być ono zrozumiane prawidłowo, musi być odczytywane w perspektywie hermeneutyki ciągłości nauczania Kościoła na temat małżeństwa. W sposób szczególny owa ciągłość ujawnia się w zestawieniu z teologią i antropologią Jana Pawła II. Obu papieży łączy przekonanie o konieczności spoglądania $\mathrm{z}$ wielkim miłosierdziem na osoby, które z różnych przyczyn pogubiły się na drodze małżeńskiej. Obydwaj podkreślają zgodnie, że miłosierne podejście do tych osób nie może zawierać w sobie żadnego minimalizowania wymagań Ewangelii. Dlatego też, mając na uwadze dokonane powyżej analizy zarówno teologiczne jak też filozoficzno-moralne, należy podnieść trzy kwestie. 
Po pierwsze: zgodnie z logiką miłosierdzia Bożego osoby, które żyją na sposób małżeński (more uxorio) z partnerem, który nie jest prawowitą małżonką albo prawowitym mężem, mogą zostać włączone do pełnej komunii z Kościołem i przystępować do Stołu Pańskiego po wcześniejszym uzyskaniu sakramentalnego rozgrzeszenia w sytuacji, w której zdecydują się na przyjęcie wstrzemięźliwości seksualnej i życia ze sobą jak „brat z siostrą”. Wymóg ten nie nosi znamion „kary za nieudany związek”, ale wynika wprost z sakramentalnego i personalistycznego rozumienia małżeństwa jako przymierza osób na wzór zjednoczenia Chrystusa z Kościołem oraz wewnętrznej miłości samych Osób Bożych. Wchodzenie w nowe związki o charakterze małżeńskim, charakteryzujące się wspólnym pożyciem płciowym, w czasie trwania ważnego węzła małżeńskiego, jest obiektywnym złem moralnym, jak też sprzeciwia się teologicznej wymowie sakramentu małżeństwa i Eucharystii. Osoby, które w tych okolicznościach pozostają aktywne seksualnie, nie mogą przystępować do Stołu Pańskiego. Co więcej, jak pokazuje zarówno analiza ludzkiego czynu oraz sumienia, żyjąc $w$ takich związkach ulegają postępującej depersonalizacji, tracąc zdolność prawego sądu sumienia o złu moralnym. Ponadto za każdym razem, kiedy poza kontekstem małżeńskim dokonywany jest akt seksualny, dochodzi wprost do „użycia” i ,uprzedmiotowienia” obojga partnerów. Owo „użycie” dokonuje się niezależnie od stopnia osobistej winy człowieka za rozkład ważnego małżeństwa i prowadzi zawsze do degradacji człowieka jako bytu osobowego. Jednakże w przypadku, w którym osoba (bądź obie osoby) decyduje się na wstrzemięźliwość, ale z uwagi na okoliczności, czy to zewnętrzne, czy wewnętrzne, konkretny akt seksualny nie nosi znamion dobrowolności, a co za tym idzie, nie dochodzi do grzechu śmiertelnego, istnieją przesłanki ku temu, aby duszpasterz po rozeznaniu dopuścił taką osobę (osoby) do sakramentu Pokuty i Pojednania oraz Eucharystii.

Po drugie: $\mathrm{z}$ dokonanych $\mathrm{w}$ niniejszym tekście analiz wynika, że może zaistnieć sytuacja, w której dana osoba (osoby) przyjęła sakrament legalnie, ale nieważnie. W takich okolicznościach, kiedy nastąpi rozpad związku, sakrament nie został „dopełniony” i de facto nie zaistniał. W świetle tego, należy - o ile to możliwe - wnioskować do sądu kościelnego o stwierdzenie jego nieważności. Jeśli okaże się to niemożliwe, wówczas duszpasterz dokonujący rozeznania takiej sytuacji, jak się wydaje, mógłby dopuścić taką osobę (osoby) do pełnego communio in sacris.

Po trzecie: należy odrzucić w kontekście nauki o sakramentalności małżeństwa tzw. zmianę paradygmatu rozumianą jako nadanie sumieniu ostatecznego prawa o decydowaniu o dobru lub złu moralnym własnego czynu. Człowiek nie może także decydować w sumieniu o teologicznym znaczeniu wymowy 
sakramentu, który zawsze pozostaje wobec niego rzeczywistością transcendentną. Autentyczna hermeneutyka wiary, pozostając wyczulona na podmiotowy wymiar przeżywania sakramentu i podmiotowy wymiar ludzkiego czynu, nie pozwala zanegować obiektywnego wymiaru zarówno sakramentu jak i wartości czynu ludzkiego.

\section{BIBLIOGRAFIA}

BARTNIK Cz. S., Dogmatyka katolicka, t. 2, Lublin 2010.

ButTiglione R., Przyjacielska odpowiedź krytykom „Amoris Laetitia”, tłum. M. Chojnacki, Kraków 2018.

FrANCISZEK, Adhortacja „Amoris Laetitia”, Rzym 2016.

JAN PAWEe II, Adhortacja „Christifideles laici”, Rzym 1988.

JAN PAWE€ II, Adhortacja „Ecclesia In Oceania”, Rzym 2001.

JAN PAWE€ II, Adhortacja „Familiaris consortio”, Rzym 1981.

JAN PAWE€ II, Adhortacja „Reconciliatio et paenitentia”, Rzym 1984.

JAN PAWE€ II, Encyklika „Dominum et Vivificantem”, Rzym 1986.

JAN PAWE€ II, Encyklika „Ecclesia de Eucharistia”, Rzym 2003.

JAN PAWE⿺ II, Encyklika „Veritatis splendor”, Rzym 1993.

JAN PAWE€ II, List do rodzin „Gratissimam sane”, Rzym 1994.

JAN PAWEŁ II, Mężczyzną i niewiastą stworzył ich. Odkupienie ciała a sakramentalność małżeństwa, Lublin 2011.

MAY W.E., La 'communio personarum' e l'atto coniugale, w: Morale Coniugale e Sacramento della Penitenza: Riflessioni sul Vademecum per i Confessori, red. A. Card, L. Trujillo, F.G. Hellin, Roma 1998, s. 135-150.

Międzynarodowa Komisja TeOlogiczna, Interpretacja dogmatów, Rzym 1988.

MÜLLER G.L., Przedmowa. Dlaczego adhortacja „Amoris Laetitia” może i powinna być rozumiana w sensie ortodoksyjnym, w: R. ButTiglione, Przyjacielska odpowiedź krytykom „Amoris Laetitia”, tłum. M. Chojnacki, Kraków 2018, s. 5-28.

POKRYWKA M., Rola Eucharystii w budowaniu małżeńskiej „communio personarum”, RT 52(2005), z. 3, s. 49-60.

RATZINGER J., List do biskupów Kościoła katolickiego na temat przyjmowania Komunii świętej przez wiernych rozwiedzionych żyjących w nowych związkach, Rzym 1994.

RATZINGER J., List do biskupów Kościoła katolickiego o niektórych aspektach Kościoła pojętego jako komunia „Communionis notio”, Rzym 1992.

SOBÓR WATYKAŃSKI II, Konstytucja duszpasterska o Kościele w świecie współczesnym „Gaudium et spes", Rzym 1965.

WoJTYŁa K., Miłość i odpowiedzialność. Lublin 2001. 


\title{
HORYZONT INTERPRETACYJNY TZW. „SYTUACJI NIEREGULARNYCH” (AMORIS LAETITIA) W ŚWIETLE NAUCZANIA JANA PAWŁA II ORAZ DOKUMENTU MIĘDZYNARODOWEJ KOMISJI TEOLOGICZNEJ PT. INTERPRETACJA DOGMATÓW
}

\author{
Stres z c z e n i e
}

Artykuł poświęcony jest problematyce interpretacji nauczania papieża Franciszka na temat tzw. „sytuacji nieregularnych” zaprezentowanych w adhortacji Amoris laetitia. Jest to problem ważny, ponieważ ta część papieskiej teologii budzi największe kontrowersje. Przyglądając się dynamice rozwoju doktryny Kościoła, można bez trudu dostrzec jej nieustanny rozwój idący w kierunku coraz lepszego wyjaśniania prawd wiary, jak też nieustannej aktualizacji nauczania. Jednakże każda aktualizacja musi być zanurzona w Tradycji, ponieważ prawda pozostaje w swojej istocie niezmienna, a jedynie zmieniać się może pewna forma językowa jej przekazu. Przyjmując hermeneutykę ciągłości, jaka cechuje rozwój doktryny Kościoła, uprawnione jest poszukiwanie właściwego kontekstu hermeneutycznego dla „sytuacji nieregularnych” w świetle teologii i antropologii Jana Pawła II oraz na tle dokumentu Międzynarodowej Komisji Teologicznej poświęconego interpretacji dogmatów.

Słowa kluczowe: Jan Paweł II; Franciszek; sytuacje nieregularne; Amoris laetitia; interpretacja dogmatów; hermeneutyka. 